\title{
The Metabolic Clearance Rate, Blood Production, Interconversion and Transplacental Passage of Cortisol and Cortisone in Pregnancy Near Term
}

\author{
INESE Z. BEITINS, FRANCIS BAYARD, ISADORE G. ANCES, \\ AVINOAM KOWARSKI, AND CLAUDE J. MIGEON ${ }^{[46]}$
}

Harriet Lane Service of Children's Medical and Surgical Center, The Johns Hopkins Hospital and University, Baltimore, Maryland, and the Department of Obstetrics and Gynecology of the University of Maryland, School of Medicine,

Baltimore, Maryland, USA

\section{Extract}

A constant infusion of ${ }^{14} \mathrm{C}$-cortisol and ${ }^{3} \mathrm{H}$-cortisone for $4 \mathrm{hr}$ was given to six pregnant women, at term, at the time of elective cesarean section. Radioactive and nonradioactive cortisol (F) and cortisone (E) concentrations were determined in maternal and cord plasma at the time when the concentration of the radioactive steroids had reached a plateau. Metabolic clearance rates (MCR), plasma levels of endogenous $\mathrm{F}$ and $\mathrm{E}$, blood production rates $(\mathrm{BP})$, conversion ratios $(\mathrm{Cr})$, and transfer constants ([p $]_{\mathrm{BB}}$ values) were calculated and compared with those obtained in eight nonpregnant women, half of whom took contraceptive medication (subjects taking "the pill") and half of whom did not (control subjects).

The MCR (F) of women near term, control subjects, and women receiving contraceptive treatment were (mean db SD) $133 \pm 47,141 \pm 37$, and $62 \mathrm{db} 24$ liters $/ 24$ $\mathrm{hr}$, respectively. The latter was significantly lower than the other two. The MCR (E) were similar in all three groups of subjects and 4-7 times greater than MCR (F).

The ratio of the endogenous $\mathrm{F} / \mathrm{E}$ for control subjects was significantly lower $(4.8 \pm$ 0.6) than that for women on the pill $(9.0 \pm 1.6)$ or for pregnant women $(7.5 \pm 1.7)$. In contrast to their mothers, the neonates had an $\mathrm{F} / \mathrm{E}$ ratio of $0.85 \pm 0.34$ with a mother /cord ratio for $\mathrm{F}$ of $4.9 \pm 2.5$ and for $\mathrm{E}$ of $0.50 \pm 0.15$.

In eight fetuses of 3-6 months of gestational age, plasma concentrations of F $(2.1 \pm$ $1.2 \mathrm{jug} / 100 \mathrm{ml})$ and $\mathrm{E}(4.7 \pm 3.3 \mathrm{jug} / 100 \mathrm{ml})$ were lower than those of six neonates $(6.3 \mathrm{db} 2.9$ for $\mathrm{F}$ and $7.2 \pm 1.2$ /ig/100 $\mathrm{ml}$ for $\mathrm{E})$.

For control subjects, the $\mathrm{Cr}^{\mathrm{F} \wedge \mathrm{E}}$ was significantly higher and the $\mathrm{Cr}^{\mathrm{E} \wedge \mathrm{F}}$ significantly lower than these ratios for pregnant women and for women on contraceptive medication. From the values of BP (F) for each subject and the corresponding transfer constant $[\mathrm{P}] \mathrm{B}^{\mathrm{E}}{ }^{\mathrm{E}}$ it was estimated that all the $\mathrm{BP}(\mathrm{E})$ for the subjects studied arose from $\mathrm{BP}$ (F), which suggested that, within the limits of error of the methods used, there was no E secretion.

\section{Speculation}

From previous studies in sheep, it was demonstrated that cortisol crossed the placenta from the mother to the fetus but that the fetus near term was also able to secrete cor- 
tisol. In this study of pregnant women we were able to calculate the maternal contribution to the fetal cortisol and cortisone concentration and to show that the fetus secretes three-fourths of its cortisol but that its cortisone was mainly maternal in origin. We were also able to show that cortisol and cortisone concentrations, similar to those at term, existed in utero as early as the 3rd month. We therefore speculate that the human fetal adrenal is capable of corticosteroid secretion early in pregnancy.

\section{Introduction}

It is now well established that cortisol crosses the placenta [22-24]. After a pulse injection of ${ }^{14} \mathrm{G}$-cortisol in pregnant women at term, radioactivity was found in the cord plasma and amniotic fluid [23]. Fetal concentrations were approximately one-third of maternal values. From these studies, however, it was impossible to establish whether the fetus secreted its own cortisol. It was thought that it relied mainly on the maternal cortisol which crossed the placenta $[1,22,23]$.

In sheep, after a constant infusion of ${ }^{14} \mathrm{G}$-cortisol in the maternal circulation and ${ }^{3} \mathrm{H}$-cortisol in the fetal circulation, we were able to confirm that cortisol crossed the placenta but that the fetus near term secreted its own cortisol [4]. A small amount of fetal cortisol, relative to the maternal cortisol concentration, crossed the placenta to the mother. However, because of major differences in placental structure and in cortisol-binding globulin, these results do not necessarily reflect the situation in human pregnancy.

In order to study the question of maternal-fetal cortisol and cortisone relationships, women at term received a constant infusion of ${ }^{14} \mathrm{C}$-cortisol and ${ }^{3} \mathrm{H}$-cortisone before elective cesarean section. After attaining a plateau of radioactive steroids, the relative amounts of radioactivity in the maternal and cord plasma at delivery were compared.

Micromethods for the measurement of $F$ and $E$ are available $[4,25]$ and enabled us to calculate the specific activities in both maternal and cord plasmas. We were also able to calculate the percentage of maternal contribution of $\mathrm{F}$ and $\mathrm{E}$ to the fetal concentration of these hormones.

In cord plasma the concentration of $\mathrm{E}$ has been found to exceed that of $\mathrm{F}[8,12,17,30,31,36,38]$. This reversed ratio persisted in the newborn infant up to the age of about 3 weeks. We obtained blood from fetuses after therapeutic abortion and were able to show that a similar pattern existed as early as approximately the 3rd month of intrauterine life.

The conversion ratios of $\mathrm{F}$ to $\mathrm{E}$ and $\mathrm{E}$ to $\mathrm{F}$ in pregnancy were compared with those of control subjects and women taking contraceptive medications. Transfer constants from $\mathrm{F}$ to $\mathrm{E}$ and $\mathrm{E}$ to $\mathrm{F}$ were also calculated.

Materials and Methods

\section{Patients}

Six healthy pregnant women ranging in age from 21 to 27 years were studied. All attended the Prenatal Clinic at the University of Maryland Hospital and had normal, uncomplicated pregnancies. Because of previous cesarean sections, all were admitted at 38-40 weeks of gestation for an elective cesarean section the following morning. The protocol was carefully explained and a signed consent obtained. During the $2 \mathrm{hr}$ before surgery, they were supine, under close supervision. They were given epidural anesthesia until delivery and then halothane. All underwent uncomplicated delivery and had normal, healthy infants, the Apgar scores ranging from 7 to 10 . It must be noted that maternal and fetal stress were minimal up to the time of delivery.

Four women ranging in age from 21 to 44 years, who were taking no medication and four women 21-32 years old who had been taking contraceptive medication (each pill contained $1 \mathrm{mg}$ Norethindrone and $0.05 \mathrm{mg}$ ethinyl estradiol or its 3-methyl ether derivative) for at least 3 months were studied. All signed an informed consent. In order to avoid the effects of diurnal variation, all of the studies were performed after 4 PM.

Eight grossly normal human fetuses were obtained immediately after therapeutic abortion by hysterotomy. All pregnancies were uncomplicated and abortions were done for psychiatric indications only.

Experimental Design

At $6 \mathrm{AM}$ the pregnant women were brought to the operating room and a constant infusion was started. An infusion of $0.8 \mathrm{M} C i$ (about 5 jug) ${ }^{14} \mathrm{C}$-cortisol $\left({ }^{14} \mathrm{C}-\mathrm{F}\right.$, sp act $55 \mathrm{mCi} / \mathrm{mM}$ ) and $3.2 \mathrm{pCi}$ (about $22 \mathrm{ng}$ ) $1,2-{ }^{3} \mathrm{H}-$ cortisone $\left({ }^{3} \mathrm{H}-\mathrm{E}\right.$, sp act $\left.53 \mathrm{Ci} / \mathrm{mni}\right)$ mixed with $50 \mathrm{ml}$ $5 \%$ dextrose was administered at a rate of $2.9 \mathrm{ml}$ for the first minute and at a rate of $0.145 \mathrm{ml} / \mathrm{min}$ thereafter with a constant infusion pump [39]. The radioactive 
materials [40] had been purified by chromatography before storage in ethanol. After approximately $3 \mathrm{hr}$ of constant infusion, four heparinized blood samples were obtained from the opposite arm of the mother at about 10-min intervals. At the time of delivery by cesarean section another heparinized blood sample was obtained simultaneously from the maternal vein and the cord vein. The infusion needle was removed from the mother's hand and 2-min effluxes were collected into five counting vials for the determination of the infusion rate. The blood samples were centrifuged and the plasma stored at $-20^{\circ}$ until assayed.

An identical experimental design was used in the control women and women receiving contraceptives. Because of a more controlled situation the first samples were obtained exactly at $3 \mathrm{hr}$ and $30 \mathrm{~min}$ and every 10 min thereafter for the next four samples.

Immediately after the hysterotomy, blood was obtained by cardiac puncture or cord exsanguination. The fetus was weighed and a crown to rump measurement obtained. The plasma was separated and stored as above.

\section{Measurement of Radioactive Cortisol and Cortisone in Plasma}

Before the plasma was extracted with distilled chloroform, $200 n g$ of $\mathrm{F}$ and $\mathrm{E}$ were added to each plasma aliquot for recovery purposes. Paper chromatography was performed in a Bush system: benzene-methanolwater $(100 / 50 / 50)$, for $5 \mathrm{hr}$.

In this system the tetrahydro compounds were well separated from the $\mathrm{F}$ and $\mathrm{E}$ areas which were visualized under ultraviolet light. The paper was eluted with methanol, dried, and the eluate redissolved in $1.0 \mathrm{ml}$ methanol. From this, $0.05 \mathrm{ml}$ was compared with $\mathrm{F}$ and E standards by the Porter and Silber color reaction [13, 28]. Another $0.8 \mathrm{ml}$ was transferred to a counting vial, dried, and scintillation fluid added. The samples were counted in a scintillation counter [41] with an efficiency of $60 \%$ for ${ }^{3} \mathrm{H}$ and $80 \%$ for ${ }^{\mathrm{M}} \mathrm{G}$ preset to count either 10,000 counts of ${ }^{3} \mathrm{H}$ or $40 \mathrm{~min}$. The final counts were corrected for recovery. The five vials containing the effluxes which were used for the calculation of infusion rate were treated in a similar manner.

\section{Plasma Concentration of $F$ and $E$}

The protein-binding radioassay first described by Murphy [4, 25] was ușed. Approximately $500 \mathrm{cpm}{ }^{3} \mathrm{H}-\mathrm{F}$ and ${ }^{3} \mathrm{H}-\mathrm{E}$ were added to each plasma sample for recovery purposes. The plasma sample was then extracted with distilled chloroform and paper chromatography performed as described above. Plasma from pregnant women (dilution, $0.33 \%$ ) was used for the binding of $\mathrm{F}$

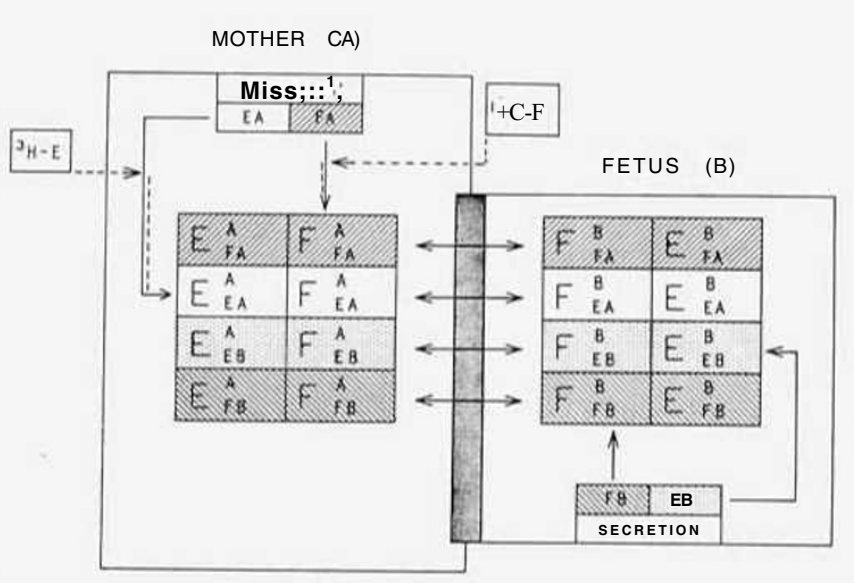

Fig. 1. Theoretical model with two pools, maternal pool $(A)$ and fetal pool $(B)$, separated by the placenta. Both cortisol $(F)$ and cortisone (£) are secreted, can interconvert and can cross the placenta. (See Theoretical Model under Materials and Methods for detailed description of model.)

and chicken plasma (dilution, $4.5 \%$ ) for the binding of E. Details for the method have been described previously [4]. The coefficient of variation on the quality control specimens for $\mathrm{F}$ was $10 \%$ and for $\mathrm{E}$ was $13 \%$.

\section{Theoretical Model}

As can be seen in Figure 1, two separate pools (maternal and fetal) communicate by means of the placenta. Two hormones, $\mathrm{F}$ and $\mathrm{E}$, are secreted into each pool. Both hormones can interconvert in each pool and cross the placenta to the other pool. Using the symbols: $\mathrm{A}=$ maternal pool; $\mathrm{B}=$ fetal pool; $\mathrm{FA}=$ cortisol originally secreted in maternal pool; $\mathrm{FB}=$ cortisol originally secreted in fetal pool; EA = cortisone originally secreted in maternal pool; EB = cortisone originally secreted in fetal pool the hormones in each pool can be represented as follows: $(\mathrm{F}) \mathfrak{£}_{\mathrm{A}}=\mathrm{F}$ in maternal pool derived from $\mathrm{F}$ originally secreted in maternal pool; $(\mathrm{F}) \mathfrak{E}_{\mathrm{B}}=\mathrm{F}$ in maternal pool derived from $\mathrm{F}$ originally secreted in fetal pool; $(\mathrm{F})$ ? $\mathrm{B}=\mathrm{F}$ in fetal pool derived from $\mathrm{F}$ originally secreted in fetal pool; $(\mathrm{F}) ?_{\mathrm{A}}=\mathrm{F}$ in fetal pool derived from $\mathrm{F}$ originally secreted in maternal pool (similarly for $(\mathrm{E})_{\mathrm{EA}}^{\mathrm{A}},(\mathrm{E})_{\mathrm{EB}}^{\mathrm{A}},(\mathrm{E})_{\mathrm{EB}}^{\mathrm{B}}$, and $\left.(\mathrm{E})_{\mathrm{EA}}^{\mathrm{B}}\right)$.

In addition, if there is $\mathrm{E}$ secretion, one must consider the amounts of $\mathrm{F}$ which were derived from $\mathrm{E}$, and vice versa: $\left(\mathrm{F}^{\mathrm{A}} \mathrm{E}_{\mathrm{A}}=\mathrm{F}\right.$ in maternal pool derived from $\mathrm{E}$ originally secreted in maternal pool; $(\mathrm{F}) \mathrm{EB}=\mathrm{F}$ in maternal pool derived from $\mathrm{E}$ originally secreted in fetal pool; $(\mathrm{F}) \mathrm{EB}=\mathrm{F}$ in fetal pool derived from $\mathrm{E}$ originally secreted in fetal pool; $(\mathrm{F})_{\mathrm{EA}}^{\mathrm{B}}=\mathrm{F}$ in fetal pool derived from $\mathrm{E}$ originally secreted in maternal pool (similarly for $(E) \hat{p}_{A}^{A}$, $(\mathrm{E}) \mathrm{F} \mathrm{B},\left.(\mathrm{E})\right|_{\mathrm{B}}>$ and $\left.(\mathrm{E}) \mathrm{p}_{\mathrm{A}}^{\mathrm{B}}\right)-$ 
As shown in Figure 1, the total $F$ in maternal pool will be: $(\mathrm{F})^{\mathrm{A}}=(\mathrm{F}) \mathrm{F}_{\mathrm{A}}^{\mathrm{A}}+(\mathrm{F}) \mathfrak{E}_{\mathrm{B}}+(\mathrm{F}) \mathrm{i},+(\mathrm{F}) \mathfrak{E}_{\mathrm{B}}$.

Specific activity. When ${ }^{\mathrm{I}} \mathrm{C}-\mathrm{F}$ and ${ }^{3} \mathrm{H}-\mathrm{E}$ are infused in the mother at a constant rate, during a period of constant maternal secretion of $\mathrm{F}$ and $\mathrm{E}$, the specific activities related to ${ }^{14} \mathrm{C}$ at equilibrium will be $\mathrm{sp}$ act $(\mathrm{F})_{\mathrm{FA}}^{\mathrm{A}}=\mathrm{sp}$ $\operatorname{act}(\mathrm{E})_{\mathrm{FA}_{\mathrm{A}}}^{\mathrm{A}}=\mathrm{sp}$ act $(\mathrm{F})_{\mathrm{FA}}^{\mathbf{B}}=\mathrm{sp}$ act $(\mathrm{E})_{\mathrm{FA}}^{\mathbf{B}}=\left({ }^{14} \mathrm{C}-\mathrm{F}\right.$ infusion rate $) /(\mathrm{F}$ secretion rate in mother $)$ and the specific activities related to ${ }^{3} \mathrm{H}$ will be $\mathrm{sp}$ act $(\mathrm{E}) \mathrm{B}_{\mathrm{A}}=$ $\mathrm{sp}$ act $(\mathrm{F}) \mathrm{E}_{\mathrm{A}}^{\mathbf{A}}=\mathrm{sp}$ act $(\mathrm{E}) 1_{\mathrm{A}}=\mathrm{sp}$ act $\left.(\mathrm{F})\right)_{\mathrm{EA}}^{\mathbf{B}}=\left({ }^{3} \mathrm{H}-\mathrm{E}\right.$ infusion rate $) /(\mathrm{E}$ secretion rate in mother).

For cortisol, equilibrium is reached when all of $(\mathrm{F})_{\mathrm{FA}}^{\mathrm{A}}$ and $(\mathrm{E})_{\mathrm{FA}}^{\mathbf{A}}$, as well as all of $(\mathrm{F})_{\mathrm{FA}}^{\mathbf{B}}$ and $(\mathrm{E})_{\mathrm{FA}}^{\mathbf{B}}$, originates from cortisol secreted in the maternal pool after the onset of the ${ }^{14} \mathrm{C}-\mathrm{F}$ infusion. It will be similar for cortisone.

Metabolic clearance rate. The metabolic clearance rate of $F$ and $E$ in the maternal pool can be calculated as follows: $\operatorname{MGR}(\mathrm{F})^{\mathrm{A}}=$ (rate of infusion of $\left.{ }^{14} \mathrm{C}-\mathrm{F}\right) /(\mathrm{ma}-$ ternal plasma concentration of ${ }^{14} \mathrm{C}-\mathrm{F}$ at equilibrium); $\operatorname{MCR}(\mathrm{E})^{\mathrm{A}}=$ (rate of infusion of $\left.{ }^{3} \mathrm{H}-\mathrm{E}\right) /($ maternal plasma concentration of ${ }^{3} \mathrm{H}-\mathrm{E}$ at equilibrium).

Blood production rate. Although the secretion rate of $\mathrm{F}$ and $\mathrm{E}$ by the mother cannot be measured, the blood production rate in the maternal pool can be calculated as follows: $\mathrm{BP}(\mathrm{F})^{\mathrm{A}}=\operatorname{MCR}(\mathrm{F})^{\mathrm{A}} \mathrm{X}$ plasma concentration of $(\mathrm{F})^{\mathrm{A}}$ at equilibrium; $\mathrm{BP}(\mathrm{E})^{\mathrm{A}}=\operatorname{MCR}(\mathrm{E})^{\mathrm{A}} \mathrm{X}$ plasma concentration of $(\mathrm{E})^{\mathrm{A}}$ at equilibrium; where $(\mathrm{F})^{\mathrm{A}}=(\mathrm{F})_{\mathrm{FA}}^{\mathrm{A}}+(\mathrm{F}) £_{\mathrm{A}}+(\mathrm{F})_{\mathrm{B}}^{\mathrm{A}}+(\mathrm{F}) \mathfrak{£}_{\mathrm{B}} ;(\mathrm{E})^{\mathrm{A}}=$ $(\mathrm{E})^{\wedge} \mathrm{A}+(\mathrm{E})_{\mathrm{FA}}^{\mathrm{A}}+(\mathrm{E}) £ \mathrm{~B}+(\mathrm{E})_{\mathrm{FB}}^{\mathrm{A}}$.

The $\mathrm{BP}(\mathrm{F})^{\mathrm{A}}$ is the sum of the blood productions of $(\mathrm{F})_{\mathrm{FA}}^{\mathrm{A}}(\mathrm{F}) £ \mathrm{~A},\left(\mathrm{~F} \mathrm{~F}_{\mathrm{B}}^{\mathrm{A}}\right.$, and $(\mathrm{F})^{\wedge}$. Hence, $\mathrm{BP}(\mathrm{F})^{\mathrm{A}}$ includes all cortisol productions in the maternal pool, whether it was secreted as F or converted from E, and whether it was of maternal or fetal origin.

Conversion ratios. The conversion ratios were calculated as follows: $\mathrm{Cr}=$ (concentration of product of conversion from the infused precursor at equilibrium $) /($ concentration of infused precursor at equilibrium).

The transfer constant of $F$ to $E$ is the fraction of the blood production rate of $\mathrm{F}$ that is converted into $\mathrm{E}$ in blood. Therefore, in the mother: $\left[p \mid l \sim^{\wedge}=(\mathrm{MCR}\right.$ $(\mathrm{E})^{\mathrm{A}} \mathrm{X}$ maternal concentration of ${ }^{14} \mathrm{C}-\mathrm{E}$ at equilibrium $) /\left(\operatorname{MCR}(\mathrm{F})^{\mathrm{A}} \mathrm{X}\right.$ maternal concentration of ${ }^{14} \mathrm{C}-\mathrm{F}$ at equilibrium) and similarly, $\left.{ }_{\mathrm{P}}\right] \overrightarrow{\mathrm{B}}^{\mathrm{F}}=\left(\mathrm{MCR}(\mathrm{F})^{\mathrm{A}} \mathrm{X}\right.$ maternal concentration of ${ }^{3} \mathrm{H}-\mathrm{F}$ at equilibrium $) /(\mathrm{MCR}$ $(\mathrm{E})^{\mathrm{A}} \mathrm{X}$ maternal concentration of ${ }^{3} \mathrm{H}-\mathrm{E}$ at equilibrium).

Blood production rate of cortisone in the mother. In our theoretical model, at equilibrium, the contribution of the blood production of $F$ to the blood production of $E$ can be determined as: $\mathrm{BP}(\mathrm{F})^{\mathrm{A}} \mathrm{X}[\mathrm{P}]^{\mathrm{B}} \mathrm{B}^{\mathrm{E}}$. If this value is found to be equal to the blood production of $\mathrm{E}$ measured directly, in other words, if $\mathrm{BP}(\mathrm{F})^{\mathrm{A}} \mathrm{X}\left[\mathrm{P}^{\mathrm{B}} \mathrm{B}^{\mathrm{E}}=\right.$
$\mathrm{BP}(\mathrm{E})^{\mathrm{A}}$, then one could conclude that there is no maternal secretion of $E$. Under these conditions, $(E) \mathrm{E}_{\mathrm{A}}$ in Figure 1 would be nil, resulting in $(\mathrm{F}) \mathrm{E}_{\mathrm{A}}=(\mathrm{F}) \mathrm{E}_{\mathrm{A}}=$ $(\mathrm{E})^{\mathrm{E}^{\mathrm{E}}} \mathrm{E}_{\mathrm{A}}=0$. In addition, it would imply that there is no crossing of $\mathrm{E}$ from the fetus to the mother. It must be noted, however, that a transplacental transfer may be significant for the fetus and yet insignificant for the maternal pool because of the difference in sizes of the two pools.

Percentage of fetal pool originating from maternal secretion. At equilibrium, one can calculate the specific activity of $\mathrm{F}$ in the maternal pool in relation to ${ }^{14} \mathrm{C}$ : $\mathrm{sp}$ act $(\mathrm{F})^{\mathrm{A}}=$ (maternal concentration $\left.{ }^{14} \mathrm{C}-\mathrm{F}\right) /\left(\mathrm{F}_{\mathbf{F A}}^{\mathrm{A}}+\mathrm{F}_{\mathrm{A}}+\mathrm{F}_{\mathrm{FB}}^{\mathrm{A}}+\right.$ $\mathrm{FEB}$ )- If we postulate that the maternal secretion of $\mathrm{E}$ is not significant $\left(\mathrm{FE}_{\mathrm{A}} \sim 0\right)$, and that the contribution of fetal hormones to the maternal pool is small $\left(F_{\mathrm{FB}}^{\mathrm{A}}-\mathrm{f}\right.$ $F E$ is insignificant in relation to $\left.F_{F A}^{A}\right)$, then: $s p$ act $(\mathrm{F})^{\mathrm{A}}=\operatorname{sp}$ act $(\mathrm{F})_{\mathrm{F}_{\mathrm{A}}}^{\mathrm{A}}=\left(\right.$ maternal concentration $\left.{ }^{14} \mathrm{C}-\mathrm{F}\right) /$ $\left(\mathrm{F}_{\mathrm{FA}}^{\mathrm{A}}\right)$, since $\mathrm{sp}$ act $(\mathrm{F})_{\mathrm{FA}}^{\mathrm{A}}=\operatorname{sp}$ act $(\mathrm{F})_{\mathrm{FA}}^{\mathrm{B}}=$ (fetal concentration $\left.{ }^{\mathrm{W}} \mathrm{C}-\mathrm{F}\right) /\left(\left.\mathrm{F}\right|_{\mathrm{A}}\right)$, then $\mathrm{F}_{\mathrm{FA}}^{\mathrm{B}}=$ (fetal concentration $\left.{ }^{14} \mathrm{C}-\mathrm{F}\right) /\left(\mathrm{sp}\right.$ act $\left.(\mathrm{F}){ }^{\mathrm{A}}\right)$.

It is also possible to calculate the percentage of $\mathrm{F}$ in the fetal pool which was contributed by maternal secre tion of $\mathrm{F}$

$$
\begin{aligned}
& =\frac{F_{F_{A}}^{B}}{F_{F A}^{B}+F_{E A}^{B}+F_{E B}^{B}+F_{F B}^{B}} \times 100 \\
& =\frac{\text { Fetal concentration }{ }^{14} \mathrm{C}-\mathrm{F}}{\left(\mathbf{F}_{\mathbf{F} . \mathbf{A}}^{\mathbf{B}}+\mathbf{F}_{\mathrm{EA}}^{\mathrm{B}}+\left.\mathrm{F}\right|_{\mathrm{B}}+\left.\mathrm{F}\right|_{\mathrm{B}}\right) \mathrm{X} \text { sp act }(\mathrm{F}) \mathrm{A}} \times 100 \\
& =\frac{\mathrm{sp} \operatorname{act}(\mathrm{F})^{\mathrm{B}}}{\mathrm{sp} \operatorname{act}(\mathrm{F})^{\mathrm{A}}} \times 100
\end{aligned}
$$

If our original postulate that $\mathrm{FE}_{\mathrm{A}}+\mathrm{F}_{\mathrm{F}_{\mathrm{B}}}^{\mathrm{A}}+\mathrm{FEB} \sim 0$ was not correct, then one would have $\mathrm{sp}$ act $(\mathrm{F})^{\mathrm{A}}<\mathrm{sp}$ act $(\mathrm{F})_{\mathrm{FA}}^{\mathrm{A}}$ and, therefore, the percentage calculated above would be overestimated.

\section{Statistics}

Statistical evaluation consisted of $t$ test and paired $t$ test [11].

\section{Results}

Metabolic Clearance Rate and Blood Production of $F$ and $E$ in Pregnant and Nonpregnant Women

The amounts of radioactivity infused and the mean concentrations of ${ }^{3} \mathrm{H}$ and ${ }^{14} \mathrm{C}-\mathrm{F}$ and ${ }^{14} \mathrm{C}-\mathrm{E}$ in plasma at the time of equilibrium are presented in Table I. From these values the MCR of $F$ and $E$ could be calculated and are expressed in liters $/ 24 \mathrm{hr}$ and liters $/ \mathrm{m}^{2} / 24 \mathrm{hr}$ (Table II). Inasmuch as the concentrations of $\mathrm{E}$ and $\mathrm{F}$ 
Table 1. Infusion rates of ${ }^{14} \mathrm{C}$-cortisol $\left({ }^{1 !} \mathrm{C}-\mathrm{F}\right)$ and ${ }^{14} \mathrm{C}$-cortisone $\left({ }^{14} \mathrm{C}\right.$-E) and ${ }^{3} \mathrm{H}$-cortisol $\left({ }^{3} \mathrm{H}-\mathrm{F}\right)$ and ${ }^{3} \mathrm{H}$-cortisone $\left({ }^{3} \mathrm{H}\right.$-E $)$ plasma levels of radioactive steroids at equilibrium in pregnant women, in cord blood, and in nonpregnant women ${ }^{1}$

\begin{tabular}{|c|c|c|c|c|c|c|c|c|c|c|}
\hline \multirow{2}{*}{ ouujects $j$} & \multirow{2}{*}{$\begin{array}{l}\text { Rate, } \\
\mathrm{cpm} / \mathrm{m}\end{array}$} & \multicolumn{2}{|c|}{ "C-F, cpm/100 ml } & \multicolumn{2}{|c|}{ "C-E, cpm/100 ml } & \multirow{2}{*}{$\begin{array}{l}\text { Rate, } \\
\mathrm{cpm} / \mathrm{m}\end{array}$} & \multicolumn{2}{|c|}{${ }^{\mathrm{s}} \mathrm{H}-\mathrm{F}, \mathrm{cpm} / 100 \mathrm{ml}$} & \multicolumn{2}{|c|}{ 3H-E, cpm/100 ml } \\
\hline & & Mother & Cord & Mother & Cord & & Mother & Cord & Mother & Cord \\
\hline \multicolumn{11}{|l|}{ Pregnancy } \\
\hline 1 & 4,770 & 6,930 & 260 & 950 & 1,370 & 14,620 & 16,470 & 990 & 3,720 & 3,320 \\
\hline 2 & 2,645 & 5,470 & 320 & 770 & 1,210 & 7,530 & 11,230 & 760 & 2,660 & 3,070 \\
\hline 3 & 3,885 & 4,630 & 280 & 790 & 1,060 & $.12,115$ & 10,330 & 690 & 2,920 & 2,640 \\
\hline 4 & 4,160 & 3,720 & 230 & 510 & 1,280 & 15,045 & 11,220 & 1,130 & 3,750 & 5,010 \\
\hline 5 & 4,410 & 4,220 & 240 & 640 & 850 & 13,515 & 9,090 & 760 & 2,330 & 2,230 \\
\hline 6 & 4,260 & 3,290 & 190 & 630 & 890 & 14,260 & 9,620 & 490 & 2,390 & 2,340 \\
\hline \multicolumn{11}{|l|}{ Control subjects } \\
\hline 7 & 3,330 & \multicolumn{2}{|c|}{3,000} & \multicolumn{2}{|c|}{620} & 10,165 & \multicolumn{2}{|c|}{5,220} & \multicolumn{2}{|c|}{2,630} \\
\hline 8 & 2,360 & \multicolumn{2}{|c|}{2,810} & \multicolumn{2}{|c|}{500} & 8,225 & \multicolumn{2}{|c|}{4,710} & \multicolumn{2}{|c|}{2,290} \\
\hline 9 & 4,810 & \multicolumn{2}{|c|}{3,760} & \multicolumn{2}{|c|}{670} & 13,170 & \multicolumn{2}{|c|}{7,380} & \multicolumn{2}{|c|}{2,370} \\
\hline 10 & 2,115 & \multicolumn{2}{|c|}{3,000} & \multicolumn{2}{|c|}{590} & 6,920 & \multicolumn{2}{|c|}{6,860} & \multicolumn{2}{|c|}{2,560} \\
\hline \multicolumn{11}{|l|}{ "On pill" } \\
\hline 11 & 2,530 & \multicolumn{2}{|c|}{10,260} & \multicolumn{2}{|c|}{1,160} & 7,535 & \multicolumn{2}{|c|}{20,960} & \multicolumn{2}{|c|}{4,420} \\
\hline 12 & 4,195 & \multicolumn{2}{|c|}{8,570} & \multicolumn{2}{|c|}{930} & 12,835 & \multicolumn{2}{|c|}{17,590} & \multicolumn{2}{|c|}{3,440} \\
\hline 13 & 4,030 & & & & & 10,905 & & & & \\
\hline 14 & 2,810 & 7, & & & & 8,585 & & & & \\
\hline
\end{tabular}

Table II. Metabolic clearance rate (MCR), blood production rate (BPR), and conversion ratio (Cr) of cortisol (F) and cortisone (E) in pregnant and nonpregnant women ${ }^{1}$

\begin{tabular}{|c|c|c|c|c|c|c|c|c|c|c|c|}
\hline \multirow[b]{2}{*}{ Subjects } & \multicolumn{2}{|c|}{$\operatorname{MCR}(\mathrm{F})$} & \multirow{2}{*}{$\underset{\mathrm{mg} / \mathrm{mV} 24 \mathrm{hr}}{\mathrm{BP}(\mathrm{F})}$} & \multirow{2}{*}{$\mathrm{Cr}^{\mathrm{F}}=$} & \multirow[b]{2}{*}{$w i \mathrm{~B}$} & \multicolumn{2}{|c|}{ MCR(E) } & \multirow{2}{*}{$\underset{\mathrm{mg} / \mathrm{mV} 24 \mathrm{hr}}{\mathrm{BP}(\mathrm{E})}$} & \multirow{2}{*}{$\mathrm{Cr}_{-}^{\mathrm{E}}{ }_{-}^{\mathrm{F}}$} & \multirow{2}{*}{$\stackrel{\mathrm{F}}{\mathrm{MB}-\mathrm{B}^{\mathrm{F}}}$} & \multirow{2}{*}{$\begin{array}{l}\text { Contribution } \\
\text { of BP(F) to } \\
\text { BP(E), \% }\end{array}$} \\
\hline & $\begin{array}{l}\text { liters/ } \\
24 \mathrm{hr}\end{array}$ & $\begin{array}{c}\text { liters } / \mathrm{mV} \\
24 \mathrm{hr}\end{array}$ & & & & liters $/ 24 \mathrm{hr}$ & $\begin{array}{l}\text { liters } / \mathrm{mV} \\
24 \mathrm{hr}\end{array}$ & & & & \\
\hline \multicolumn{12}{|l|}{ Pregnancy } \\
\hline / & 99 & 66 & 16.5 & 0.14 & 0.78 & 566 & 377 & 9.4 & 4.43 & 0.78 & 136 \\
\hline 2 & 67 & 44 & 10.5 & 0.14 & 0.82 & 408 & 268 & 8.0 & 4.22 & 0.72 & 107 \\
\hline 3 & 121 & 72 & 17.3 & 0.17 & 0.83 & 590 & 351 & 10.5 & 3.54 & 0.73 & 136 \\
\hline 4 & 161 & 97 & 26.2 & 0.14 & 0.59 & 687 & 414 & 16.5 & 2.99 & 0.83 & 94 \\
\hline 5 & 150 & 78 & 20.3 & 0.15 & 0.84 & 835 & 434 & 15.2 & 3.90 & 0.70 & 112 \\
\hline 6 & 200 & 104 & 24.9 & 0.19 & 0.82 & 860 & 447 & 22.3 & 4.03 & 0.94 & 93 \\
\hline Mean & 133 & 77 & 19.3 & 0.15 & 0.78 & 658 & 382 & 13.7 & 3.85 & 0.78 & 113 \\
\hline$\pm \mathrm{SD}$ & \pm 47 & \pm 22 & \pm 5.8 & \pm 0.02 & \pm 0.09 & \pm 172 & \pm 66 & \pm 5.4 & \pm 0.51 & \pm 0.09 & \pm 19 \\
\hline \multicolumn{12}{|c|}{ Control subjects } \\
\hline 7 & 159 & 108 & 1.6 & 0.21 & 0.73 & 558 & 379 & 1.1 & 1.99 & 0.57 & 106 \\
\hline 8 & 120 & 65 & 6.3 & 0.18 & 0.76 & 517 & 280 & 5.3 & 2.06 & 0.48 & 90 \\
\hline 9 & 184 & 115 & 2.9 & 0.18 & 0.78 & 801 & 501 & 2.5 & 3.11 & 0.72 & 91 \\
\hline 10 & 101 & 63 & 2.2 & 0.20 & 0.76 & 388 & 242 & 2.1 & 2.68 & 0.70 & 80 \\
\hline Mean & 141 & 88 & 3.3 & 0.19 & 0.76 & 566 & 350 & 2.8 & 2.46 & 0.62 & 92 \\
\hline$\pm \mathrm{SD}$ & \pm 37 & \pm 28 & \pm 2.1 & \pm 0.01 & \pm 0.02 & \pm 173 & \pm 116 & \pm 1.8 & \pm 0.53 & \pm 0.11 & \pm 11 \\
\hline \multicolumn{12}{|l|}{ "On pill" } \\
\hline 11 & 36 & 23 & 1.2 & 0.11 & 0.78 & 246 & 157 & 0.9 & 4.74 & 0.69 & 104 \\
\hline 12 & 70 & 39 & 5.3 & 0.11 & 0.83 & 538 & 300 & 3.9 & 5.11 & 0.67 & 113 \\
\hline 13 & 91 & 59 & 5.1 & 0.13 & 0.73 & 505 & 327 & 4.2 & 4.70 & 0.85 & 90 \\
\hline 14 & 51 & 32 & 3.9 & 0.11 & 0.79 & 360 & 226 & 2.7 & 4.76 & 0.68 & 112 \\
\hline Mean & 62 & 38 & 3.9 & 0.11 & 0.78 & 412 & 253 & 2.9 & 4.83 & 0.72 & 105 \\
\hline$\pm \mathrm{SD}$ & \pm 24 & \pm 15 & \pm 1.9 & \pm 0.01 & \pm 0.04 & \pm 135 & \pm 77 & \pm 1.5 & \pm 0.19 & \pm 0.09 & \pm 11 \\
\hline
\end{tabular}

${ }^{1}$ For detailed description of model, see Theoretical Model under Materials and Methods.

in plasma (Table III), were known, it was also possible to calculate the blood production of these two steroids (Table II).

To insure that we were dealing with a steady state, an analysis of regression of the levels of radioactivity of ${ }^{3} \mathrm{H}$ and ${ }^{14} \mathrm{G}$ and nonradioactive $\mathrm{F}$ and $\mathrm{E}$ at the time of plateau was performed. In all of our experiments, the radioactive steroid concentrations in the five blood 
Table III. Plasma concentrations of cortisol (F) and cortisone (E) (,ug/100 ml) in pregnant women, cord blood, and nonpregnant women

\begin{tabular}{|c|c|c|c|c|c|c|}
\hline \multirow{2}{*}{ Subjects } & \multicolumn{2}{|c|}{$\mathrm{F}$} & \multicolumn{2}{|c|}{ E } & \multicolumn{2}{|c|}{$\mathrm{F} / \mathrm{E}$} \\
\hline & Mother & Cord & Mother & Cord & Mother & Cord \\
\hline \multicolumn{7}{|l|}{ Pregnancy } \\
\hline 1 & 25 & 4 & 2.5 & 5.5 & 10.0 & 0.73 \\
\hline 2 & 24 & 8 & 3 & 7 & 8.0 & 1.14 \\
\hline 3 & 24 & 6.5 & 3 & 9 & 8.0 & 0.72 \\
\hline 4 & 27 & 3 & 4 & 7 & 6.8 & 0.43 \\
\hline 5 & 26 & 11 & 3.5 & 8 & 7.4 & 1.38 \\
\hline 6 & 24 & 5 & 5 & 7 & 4.8 & 0.71 \\
\hline Mean & 25.0 & 6.3 & 3.5 & 7.2 & 7.5 & 0.85 \\
\hline$\pm \mathrm{SD}$ & $\pm 1 . .25$ & \pm 2.9 & \pm 0.9 & \pm 1.2 & \pm 1.7 & \pm 0.34 \\
\hline \multicolumn{7}{|c|}{ Control subjects } \\
\hline 7 & \multicolumn{2}{|c|}{1.5} & \multicolumn{2}{|c|}{0.3} & \multicolumn{2}{|c|}{5.0} \\
\hline 8 & \multicolumn{2}{|c|}{9.7} & \multicolumn{2}{|c|}{1.9} & \multicolumn{2}{|c|}{5.1} \\
\hline 9 & \multicolumn{2}{|c|}{2.5} & \multicolumn{2}{|c|}{0.5} & \multicolumn{2}{|c|}{5.0} \\
\hline 10 & \multicolumn{2}{|c|}{3.5} & \multicolumn{2}{|c|}{0.9} & \multicolumn{2}{|c|}{3.9} \\
\hline Mean & \multicolumn{2}{|c|}{4.3} & \multicolumn{2}{|c|}{0.9} & \multicolumn{2}{|c|}{4.8} \\
\hline$\pm \mathrm{SD}$ & \multicolumn{2}{|c|}{ \pm 3.7} & \multicolumn{2}{|c|}{ \pm 0.7} & \multicolumn{2}{|c|}{ \pm 0.6} \\
\hline \multicolumn{7}{|l|}{ "On pill" } \\
\hline 11 & \multicolumn{2}{|c|}{5.4} & \multicolumn{2}{|c|}{0.6} & \multicolumn{2}{|c|}{9.0} \\
\hline 12 & \multicolumn{2}{|c|}{13.5} & \multicolumn{2}{|c|}{1.3} & \multicolumn{2}{|c|}{10.4} \\
\hline 13 & \multicolumn{2}{|c|}{8.7} & \multicolumn{2}{|c|}{1.3} & & .7 \\
\hline 14 & & & & .2 & & .0 \\
\hline Mean & & .0 & & .1 & & .0 \\
\hline$\pm \mathrm{SD}$ & \pm 3 & & \pm 0 & & & \\
\hline
\end{tabular}

samples obtained after $3 \mathrm{hr}$ of constant infusion were similar for each steroid. Specifically, the differences among values were less than $15 \%$ of their mean, and linear regression lines had slopes not significantly different from zero $(P=0.5)$. Similarly, the levels of nonradioactive $\mathrm{E}$ and $\mathrm{F}$ in the five blood samples obtained at 10-min intervals at the end of the constant inftision differed from each other by less than $15 \%$ of their mean -and linear regression lines had slopes not significantly different from zero.

Hellman et al: [16] have reported that cortisol is secreted episodically by normal man. The fact that we found fairly constant levels of endogenous hormones may be related to the relatively short period of observation (40-50 $\mathrm{min}$ ). In addition, most normal subjects tend to have a high plateau in the morning, the time at which the pregnant women were studied, and a low plateau in the late afternoon and evening, the time at which the nonpregnant women were investigated [9].

The MCR (F) of women near term was $133 \pm 47$ (SD) liters/24 hr and MCR (E) was $658 \pm 172$ (SD) liters $/ 24 \mathrm{hr}$. The latter was significantly higher than the former $(\mathrm{P}<0.005)$. These values were similar $(\mathrm{P}>0.2)$ to the MCR (F) and MCR (E) of control, nonpregnant women, including values corrected for body surface area (Table II). In contrast, women who were taking contraceptive medication had significantly $(P<0.01)$ lower MCR (F) and MCR (E) (62 \pm 24 liters/24 hr and $412=\mathrm{t} 135$ liters $/ 24 \mathrm{hr}$, respectively).
The plasma concentrations of $\mathrm{F}$ and $\mathrm{E}$ in plasma are shown in Table III. In control subjects, in late afternoon, the mean plasma concentration of $\mathrm{F}$ was $4.3 \pm 3.7$ $\mathrm{Mg} / 100 \mathrm{ml}$ and of $\mathrm{E}$ was $0.9 \pm 0.6 \mathrm{Mg} / 100 \mathrm{ml}$. At a similar time, the corresponding values for women taking contraceptives were $10.7 \pm 4.7 \mathrm{Mg} / 100 \mathrm{ml}$ for $\mathrm{F}$ and $1.1 \pm 0.3$ $/ \mathrm{xg} / 100 \mathrm{ml}$ for $\mathrm{E}$. In late pregnancy, $\mathrm{F}$ and $\mathrm{E}$ levels were significantly higher.

The $F / E$ ratio in the plasma of pregnant women $(7.5 \pm 1.7)$ was similar to that of women taking contraceptive pills $(9.0 \pm 1.6)$ but significantly higher $(\mathrm{P}<$ 0.05 ) than that of women not taking medication (Table III).

In control subjects, the BP $(\mathrm{F})$ in the late afternoon was $3.3 \pm 2.1 \mathrm{mg} / \mathrm{m}^{2} / 24 \mathrm{hr}$ and that of $\mathrm{E}$ was $2.8 \pm 1.7$ $\mathrm{mg} / \mathrm{m}^{2} / 24 \mathrm{hr}$. In women taking contraceptives the BP (F) and BP (E) were $3.9 \pm 1.9 \mathrm{mg} / \mathrm{m}^{2} / 24 \mathrm{hr}$ and $2.9 \pm$ $1.5 \mathrm{mg} / \mathrm{m}^{2} / 24 \mathrm{hr}$, respectively. There was not significant difference between the control subjects and those on contraceptives. However, the values in the morning during late pregnancy were much higher for both $\mathrm{BP}(\mathrm{F})$ and BP (E) even when corrected for body surface area (Table II). It must be noted that in all subjects, pregnant or not, BP $(\mathrm{F})$ was higher than BP $(\mathrm{E})(\mathrm{P}<0.01$ on paired $t$ test).

\section{Plasma Concentrations of $F$ and $E$ in Fetuses and Neonates}

The plasma concentrations of $\mathrm{F}$ and $\mathrm{E}$ and the $\mathrm{F} / \mathrm{E}$ ratios for the neonates studied are represented in Tables III and IV and for the fetuses, in Table V. The weight and crown to rump length is given for each fetus (Table $\mathrm{V})$. All of the neonates were full term and normal in weight and length.

The mean fetal $\mathrm{F}$ concentration was $2.1 \pm 1.2 \mathrm{jug} / 100$ $\mathrm{ml}$, whereas the $\mathrm{E}$ concentration was $4.7 \pm 3.3 / \mathrm{ig} / 100$ $\mathrm{ml}$, the mean $\mathrm{F} / \mathrm{E}$ ratio being $0.64 \pm 0.48$ (Table V). In the neonate, the mean $\mathrm{F}$ concentration was $6.3 \pm 2.9$ $/ \mathrm{xg} / 100 \mathrm{ml}$, the mean $\mathrm{E}$ concentration was $7.2 \pm 1.2$ $\mathrm{Mg} / 100 \mathrm{ml}$, and the mean $\mathrm{F} / \mathrm{E}$ ratio was $0.85 \pm 0.34$ (Table III). The F/E ratio of the neonates contrasts with that of their mothers, which was $7.5 \pm 1.7$.

The plasma concentration of $\mathrm{E}$ was significantly higher than $\mathrm{F}$ in the fetuses $(\mathrm{P}<0.025$ on paired $t$ test) but not in the neonates. When the values in the plasma of mothers and neonates were compared, it was found that the maternal/cord ratio was $4.9 \pm 2.5$ (SD) for $\mathrm{F}$ and $0.5 \pm 0.15$ for $\mathrm{E}$ (Table IV). In addition, the maternal/cord ratio for ${ }^{14} \mathrm{C}-\mathrm{F}$ was about 4 times greater $(18.6 \pm 40)$ than that for endogenous $F$, which demonstrates that the fetus near term secretes cortisol and contributes significantly to its plasma $\mathrm{F}$ levels. 
Table IV. Ratios of concentrations of radioactive and nonradioactive cortisol $(\mathrm{F})$ and cortisone (E) in maternal and cord plasma ${ }^{1}$

\begin{tabular}{|c|c|c|c|c|c|c|c|c|c|c|c|c|}
\hline \multirow{2}{*}{ Subjects } & \multicolumn{6}{|c|}{$\begin{array}{c}\text { Plasma concentrations } \\
\text { mother/cord }\end{array}$} & \multicolumn{3}{|c|}{ Plasma F/E ratio in mother } & \multicolumn{3}{|c|}{ Plasma. F/E ratio in cord } \\
\hline & $\mathrm{F}$ endogen & "C-F & $\gg \mathrm{H}-\mathrm{F}$ & E endogen & "C-E & $>\mathrm{H}-\mathrm{E}$ & Endogen & ${ }^{\mathrm{M}} \mathrm{C}^{2}$ & $3 \mathrm{H} 3$ & Endogen & "C & $m$ \\
\hline \multicolumn{13}{|c|}{ Pregnancy } \\
\hline 1 & 6.3 & 26.6 & 16.5 & 0.5 & 0.7 & 1.1 & 10.0 & 7.3 & 4.4 & 0.73 & 0.2 & 0.3 \\
\hline 2 & 3.0 & 17.1 & 14.8 & 0.4 & 0.6 & 0.9 & 8.0 & 7.1 & 4.2 & 1.14 & 0.3 & 0.2 \\
\hline 3 & 3.7 & 17.5 & 15.0 & 0.3 & 0.7 & 1.1 & 8.0 & 5.9 & 3.5 & 0.72 & 0.3 & 0.3 \\
\hline 4 & 9.0 & 16.2 & 9.9 & 0.6 & 0.4 & 0.7 & 6.8 & 7.3 & 3.0 & 0.43 & 0.2 & 0.2 \\
\hline 5 & 2.4 & 17.6 & 12.0 & 0.4 & 0.8 & 1.0 & 7.4 & 6.6 & 3.9 & 1.38 & 0.3 & 0.3 \\
\hline 6 & 4.8 & 17.3 & 19.6 & 0.7 & 0.7 & 1.0 & 4.8 & 5.2 & 4.0 & 0.71 & 0.2 & 0.2 \\
\hline Mean & 4.9 & 18.7 & 14.6 & 0.50 & 0.65 & 0.97 & 7.5 & 6.6 & 3.8 & 0.85 & 0.25 & 0.25 \\
\hline$\pm \mathrm{SD}$ & \pm 2.5 & \pm 3.9 & \pm 3.4 & \pm 0.15 & \pm 0.14 & \pm 0.15 & \pm 1.7 & \pm 0.9 & \pm 0.5 & \pm 0.34 & \pm 0.06 & \pm 0.06 \\
\hline
\end{tabular}

${ }^{1}$ For detailed description of model, see Theoretical Model under Materials and Methods.

${ }^{2}$ This ratio is the same as $1 / \mathrm{Cr}^{\mathrm{F}} \wedge \mathrm{E}$.

${ }^{3}$ This ratio is the same as $\mathrm{Cr}^{\mathrm{E}+"} \mathrm{~F}$.

Table $V$. Plasma concentrations of cortisol $(F)$ and cortisone $(E)$ in human fetuses

\begin{tabular}{lrrrrrr}
\hline Subjects & $\begin{array}{c}\text { Fetal } \\
\text { weight, } \\
\text { g }\end{array}$ & $\begin{array}{c}\text { Crown- Estimated } \\
\text { rump } \\
\text { length, cm }\end{array}$ & $\begin{array}{c}\text { Cortisol, } \\
\text { getational } \\
\text { age, wk }\end{array}$ & $\begin{array}{c}\text { Corti- } \\
\text { Vo\%l } \\
100 \mathrm{ml}\end{array}$ & $\begin{array}{c}\text { Cone, } \\
\text { sone, }\end{array}$ & F/E \\
\hline jetuses & & & & & & \\
& 88 & 11.4 & 11.5 & 3.5 & 11.8 & 0.30 \\
& 220 & 14.7 & 16.5 & 3.3 & 3.5 & 0.94 \\
& 270 & 15.9 & 17.5 & 1.3 & 2.0 & 0.65 \\
& 290 & 17.0 & 18.6 & 0.9 & 6.8 & 0.13 \\
& 365 & 18.0 & 19.4 & 1.0 & 2.7 & 0.37 \\
& 420 & 17.0 & 18.6 & 0.8 & 3.8 & 0.21 \\
& 652 & 22.5 & 23.8 & 3.2 & 1.6 & 2.00 \\
Mean & 800 & 22.5 & 23.8 & 2.8 & 5.1 & 0.55 \\
\pm SD & & & & 2.1 & 4.7 & 0.64 \\
& & & & \pm 1.2 & \pm 3.3 & \pm 0.48
\end{tabular}

Full term

\begin{tabular}{lrrr}
$\quad(\mathrm{n}=6)$ & & & \\
Mean & 6.3 & 7.2 & 0.85 \\
\pm SD & \pm 2.9 & \pm 1.2 & \pm 0.34 \\
\hline
\end{tabular}

\section{Conversion Ratios and Transfer Constants}

The conversion ratios from $\mathrm{F}$ to $\mathrm{E}\left(\mathrm{Cr}^{\mathrm{F} \wedge \mathrm{E}}\right)$ and $\mathrm{E}$ to $\mathrm{F}$ $\left(\mathrm{Gr}^{\mathrm{E}_{1}>\mathrm{F}}\right)$ in nonpregnant women are shown in Table II. The transfer constants from $\mathrm{F}$ to $\mathrm{E}\left([\mathrm{P}] \mid \overrightarrow{\mathrm{B}}^{\mathrm{E}}\right)$ and $\mathrm{E}$ to $\mathrm{F}$ $\left(\mathrm{WB}^{\mathrm{B}} \mathrm{B}^{\mathrm{F}}\right)^{\text {are }}$ also represented in the table. The mean $\mathrm{Cr}^{\mathrm{F}} * \mathrm{~B}$ for control subjects was $0.19 \pm 0.01$ (SD), which was significantly higher than that for pregnant women $(0.15 \pm 0.02, P<0.01)$. and for women taking contraceptives $(0.11 \pm 0.01, P<0.005)$. In contrast, the mean $\mathrm{Gr}^{\mathrm{E} \wedge \mathrm{F}}$ for control subjects of $2.46 \pm 0.53$ was significantly lower than that for pregnant women $(3.85 \pm$ $0.34, P<0.01)$ and for women taking contraceptives (4.83 $\pm 0.19, P<0.01)$.

The $[\mathrm{P}] \mathrm{B} \mathrm{BB}^{\mathrm{E}}$ was not significantly different in pregnancy $(0.78)$, control subjects $(0.76)$, or women on contracep- tives $(0.78)$. The $[\mathrm{P}] \mid \overrightarrow{\mathrm{B}}^{\mathrm{F}}$ in control subjects $(0.62 \pm 0.11)$ was significantly lower than that for pregnant women (0.78 $\pm 0.09, P<0.05)$, but not significantly different from women taking contraceptives $(0.72 \pm 0.09)$. Taking all three groups together, the $[\mathrm{P}] \overrightarrow{\mathrm{BB}}^{\mathrm{E}}$ was significantly higher than the $[\mathrm{P}] \mathrm{B}^{\mathrm{E}} \overrightarrow{\mathrm{B}}^{\mathrm{F}}(P<0.05$ on paired $t$ test $)$.

\section{Contribution of Blood Production of Cortisol to That of Cortisone} in the Mother

As shown in the section on methods, the product $\mathrm{BP}(\mathrm{F}) \mathrm{X}[\mathrm{P}] \overrightarrow{\mathrm{BB}}^{\mathrm{E}}$ represents the contribution of $\mathrm{BP}(\mathrm{F})$ to $\mathrm{BP}(\mathrm{E})$. The contribution can be expressed as percentage of $\mathrm{BP}(\mathrm{E})$ : $\left[\left(\mathrm{BP}(\mathrm{F}) \times[\mathrm{P}] \vec{B}^{5} \vec{B}^{\mathrm{E}}\right) / \mathrm{BP}(\mathrm{E})\right] \quad \mathrm{X} 100$. This factor is equal to: $\left[\left(\operatorname{sp}\right.\right.$ act $\left.(E)^{A}\right) /\left(\operatorname{sp}\right.$ act $\left.\left.(F)^{A}\right)\right] X$ 100 and to: [(maternal concentration $\mathrm{F}) /($ maternal concentration $\mathrm{E})] \mathrm{X}\left[\left(\right.\right.$ maternal concentration $\left.{ }^{14} \mathrm{C}-\mathrm{E}\right) /$ (maternal concentration $\left.\left.{ }^{14} \mathrm{G}-\mathrm{F}\right)\right] \mathrm{X}$ 100. The values of this factor for the various subjects are shown in Table II. The mean percentage contribution of BP $(\mathrm{F})$ to BP $(\mathrm{E})$ was $113=\mathrm{t} 19 \%$ in pregnant women, $92 \pm 11 \%$ in normal women, and $105 \pm 11 \%$ in nonpregnant women receiving anticontraceptive pills. None were significantly different from $100 \%$ on a $Z$ test $(\mathrm{P}>0.1)$, which suggests that in all the subjects the BP (E) was entirely contributed by BP (F), and hence the secretion of $E$ was nil.

\section{Contribution of Maternal Secretion of $F$ to Fetal Pool of $F$ and $E$}

We have demonstrated in the method section that the contribution of the maternal $F$ in percentage to the fetal pool of $F$ can be expressed as: $\left[\left(\mathrm{sp}\right.\right.$ act $\left.(\mathrm{F})^{\mathrm{B}}\right) /(\mathrm{sp}$ act $\left.(\mathrm{F})^{\mathrm{A}}\right)$ ] X 100 or as: [(maternal concentration $\left.\left.\mathrm{F}\right)\right] /$ (fetal concentration $F)] X\left[\left(\right.\right.$ fetal concentration $\left.{ }^{14} \mathrm{G}-\mathrm{F}\right) /$ (maternal concentration $\left.\left.{ }^{14} \mathrm{C}-\mathrm{F}\right)\right] \mathrm{X}$ 100. The calculation is based on two assumptions: (/) the maternal secretion 


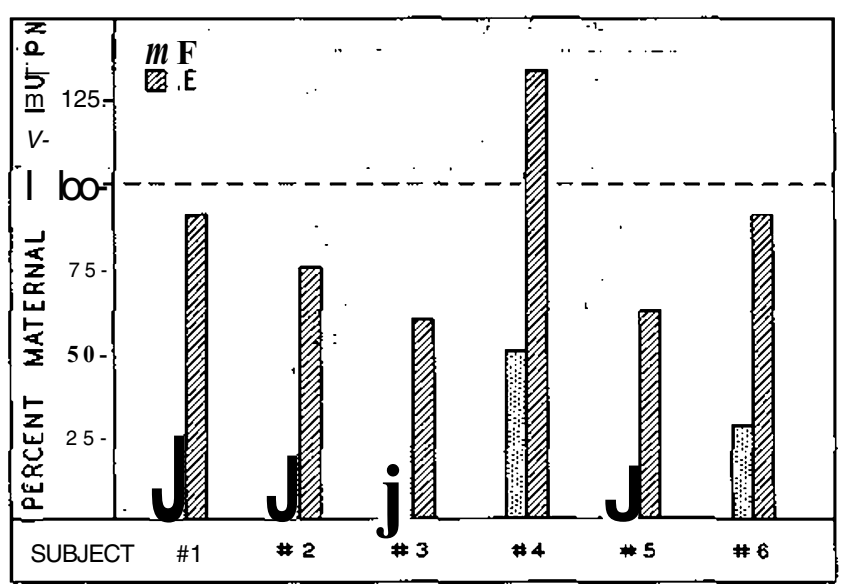

Fig. 2. Maternal contribution to fetal concentrations of cortisol and cortisone. Percentage of the fetal pools of cortisol $(F)$ and cortisone (£) originating from the maternal production of cortisol. Approximately $25 \%$ of fetal (F) and almost $90 \%$ of fetal $(\mathrm{E})$ originate from maternal $(\mathrm{F})$.

of $\mathrm{E}$ is not significant and (2) the contribution of $\mathrm{F}$ and E secreted by the fetus to the maternal pool is negligible. Our data suggest that the first assumption is correct. On the basis of the difference in size of the maternal and fetal pools, it seems fair to assume that fetal $\mathrm{F}$ and $\mathrm{E}$ contribute little to the maternal pool. Under such conditions, the maternal contribution to fetal $\mathrm{F}$ ranges from 20 to $50 \%$ with a mean of $26.7 \%$ (see Fig. 2).

The percentage contribution of the maternal secretion of $F$ to the fetal pool of $E$ can also be calculated: [(sp act $\left.(\mathrm{E})^{\mathrm{B}}\right) /\left(\mathrm{sp}\right.$ act $\left.\left.(\mathrm{F})^{\mathrm{A}}\right)\right] \times 100$ or $[($ maternal concentration $\mathrm{F}) /($ fetal concentration $\mathrm{E})] \quad \mathrm{X} \quad[($ fetal concentration $\left.{ }^{u} \mathrm{C}-\mathrm{E}\right) /\left(\right.$ maternal concentration $\left.\left.{ }^{\mathrm{U}} \mathrm{C}-\mathrm{F}\right)\right] \mathrm{X}$ 100. As can be seen in each instance, the percentage of maternal contribution to $\mathrm{E}$ exceeds that of $\mathrm{F}$. This difference is statistically significant $(P<0.01$ on a paired / test). In 1 out of 6 instances the percentage of maternal contribution of $\mathrm{F}$ exceeded $100 \%$, which is not possible and must have resulted from methodologic errors. The mean percentage contribution was $88 \pm 25 \%$ (see Fig. 2).

\section{Discussion}

The question of whether the fetus secretes its own cortisol or depends mainly on the maternal cortisol which crosses the placenta has not been answered. This is important in understanding fetal and neonatal physiology, especially under circumstances in which the mother has received pharmacologic doses of cortisone throughout her pregnancy. We have attempted to seek answers to these questions by studying the steroid kinetics in women at term who are undergoing elective cesarean section.

\section{Metabolic Clearance Rate of Cortisol and Cortisone}

The MCR (F) of pregnant women, whether corrected for body surface area or not, was similar to that of normal women but greater than that of women receiving contraceptive medication. This is a somewhat surprising finding, as one would expect values for pregnant women to be similar to those of women "on the pill," and lower than those for nonpregnant females. The amount of estrogen secretion is great in pregnancy and the amounts of estrogens contained in contraceptive pills are greater than the physiologic secretion in the nonpregnant state. Hence, pregnancy and contraceptive therapy result in increased cortisol binding [7, 20, 29], which causes a lowering of MCR (F). At the same time, it has been shown that the MCR determined in the morning is lower than that obtained in the evening [10,27]. In the present study, we elected to study the normal women and women on contraceptives in the late afternoon; i.e., at a time when cortisol secretion was expected to be fairly constant. However, the timing of the study of women scheduled for an elective cesarean section was determined by the obstetric team and all studies were very early in the morning. It would appear that the difference in time of investigation is responsible for our finding of relatively high values of MCR (F) in pregnant women when compared with women receiving contraceptive pills.

Because cortisone is poorly bound to transcortin [25], MCR (E) would be expected to be less influenced by the time of day or presence of excess circulating estrogens. Indeed, our values were not significantly different during pregnancy and the nonpregnant state. Our values of $566.0 \pm 173$ liters $/ 24 \mathrm{hr}(\mathrm{SD})$ in normal women agree with those previously reported for aldosterone which is also poorly bound to plasma proteins $[2,18,34]$. Similarly, the MCR of aldosterone is not influenced by pregnancy [34].

\section{Plasma Concentrations of Cortisol and Cortisone}

The surgical procedure used for elective cesarean section is designed to produce the least possible stress to mother and infant. Indeed, studies of plasma cortisol concentrations have shown that maternal values at delivery are not significantly different from those obtained at the end of pregnancy, but are much lower than these observed during vaginal delivery [24]. Therefore, the cortisol levels obtained in these subjects can be considered as physiologic.

The mean $\mathrm{F}$ concentration in pregnant women near term was in good agreement with 17-hydroxycorticosteroid values reported previously $[21,24]$. The mean 
plasma E concentration was $3.5 \pm 0.9 / \mathrm{jg} / 100 \mathrm{ml}$ with an $F / E$ ratio of 7.5. The values of $F$ and $E$ reported by Hillman and Giroud [17] were higher than ours, probably because these authors studied cases of vaginal delivery instead of those of elective cesarean section as in the present report. However, their ratio $\mathrm{F} / \mathrm{E}$ was in the same range.

Because of the influence of the diurnal variation, $F$ and $\mathrm{E}$ concentrations in the nonpregnant women in the afternoon were low. Their F/E ratio was 4.8 , a value somewhat higher than that reported by Seely [31]. Women taking contraceptives have increased transcortin levels and hence their plasma $\mathrm{F}$ concentrations and $\mathrm{F} / \mathrm{E}$ ratio were higher.

The human placenta is capable of progesterone synthesis as early as 6 weeks. By 10 weeks, when the fetus is $40 \mathrm{~mm}$ long, 17-, 21-, and 11/3-hydroxylase activity can be demonstrated in vitro in the fetal adrenal [37]. Thus even though the fetal adrenal lacks 3/3-hydroxysteroid dehydrogenase activity, it should be able to synthesize cortisol from placental progesterone.

Our smallest fetus was estimated to have a gestational age of 11.5 weeks from its crown-rump length of $11.4 \mathrm{~cm}$ [32]. Serum thyroxine was identified in this fetus by Greenberg et at. [15]. We found that its $\mathrm{F}$ concentration was not different from that of the older fetuses but its $\mathrm{E}$ concentration was higher. There was no progressive increase of $\mathrm{F}$ or $\mathrm{E}$ concentrations with gestational age (Table V). The mean plasma $\mathrm{F}$ concentration was $2.1 \pm$ $1.2 \mathrm{jug} / 100 \mathrm{ml}$, which was significantly lower than the $\mathrm{F}$ concentration in the cords of infants born at term by cesarean section, with minimal maternal stress $(6.3 \pm 2.9$ $\left.{ }_{\mathrm{M}} \mathrm{g} / 100 \mathrm{ml}\right)(P<0.005)$.

It has been suggested that it is a decreased concentration of $F$ in the fetal plasma that stimulates the fetal pituitary gland to produce more adrenocorticotropic hormone $(\mathrm{ACTH})$ and in turn produces the hyperplasia found in the fetal zone of the fetal adrenal cortex [37]. However, no data are presently available on the concentration of unbound $\mathrm{F}$ in the fetus and since ACTH secretion is probably controlled by "unbound" rather than "total" F, it is not possible to come to any conclusion at this time.

The fetal concentration of $\mathrm{E}$ was significantly higher than $\mathrm{F}(P<0.025$ on paired $t$ test). This can be explained by the fact that E, loosely bound to protein, readily crosses the placenta. In addition, the placenta contains an active 11/3-dehydrogenase enzyme system which converts maternal $\mathrm{F}$ to fetal $\mathrm{E}[6,26,33,35]$.

The mean concentration of $\mathrm{F}$ in the cord plasma of neonates at the time of elective cesarean section is in agreement with previous reports [21, 24]. The maternal to fetal ratio of $4.9=\mathbf{c} 2.5$ is also in agreement with previously reported ratios $[1,14,24]$. The lower $F$ concentration could be due in part to a lower concentration of transcortin in the plasma of neonates [29]. As. in the fetal samples, the E concentration of the neonates was higher than the $\mathrm{F}$ concentration in most instances.

\section{Blood Production of Cortisol and Cortisone}

Although constant levels of endogenous $\mathrm{F}$ and $\mathrm{E}$ were found in all of our subjects, the values obtained were representative of the period of study (late afternoon for the nonpregnant women and early morning for the pregnant subjects) instead of a complete 24-hr period. Therefore, it is not possible to make meaningful comparisons. Among the nonpregnant women studied at the same time of the day, BP (F) was similar in normal women and in women receiving contraceptives as a result of the fact that normal women had higher MGR (F) but lower plasma $\mathrm{F}$ concentrations.

\section{Conversion Ratios and $[\mathrm{P}] \mathrm{BB}$ Values}

The $\mathrm{Cr}^{\mathrm{F} \wedge \mathrm{E}}$ in normal women was greater than that of women receiving contraceptives and of pregnant women, whereas their $\mathrm{Cr}^{\mathrm{E}} \sim \mathrm{F}^{\mathrm{F}}$ was lower. This finding can probably be explained by the lower transcortin concentrations of the normal women.

The transfer constants, $[\mathrm{P}] \mid \overrightarrow{\mathrm{B}}^{\mathrm{E}}$ and $[\mathrm{P}] \overrightarrow{\mathrm{BB}}^{\mathrm{F}}$, reflected the trend of the values of the conversion ratios.

\section{Contribution of Blood Production of Cortisol to That of Cortisone} in the Mother

In the three groups of women the contribution of $\mathrm{BP}(\mathrm{F})$ to $\mathrm{BP}$ (E) was not significantly different from $\mathrm{BP}(\mathrm{E})$; this in itself suggested a lack of $\mathrm{E}$ secretion. In 2 cases out of the 14 studied, the value of the contribution of BP (F) was $136 \%$ greater than the actual value of BP (E). Such results were probably due to technical errors in methodology. At the same time, it shows that it is difficult to make a definitive statement regarding an absence of secretion of $E$ in our subjects.

In a previous study, in which an intravenous pulse injection of ${ }^{3} \mathrm{H}-\mathrm{E}$ and ${ }^{\mathrm{W}} \mathrm{C}-\mathrm{F}$ was given, the determination of ${ }^{3} \mathrm{H} /{ }^{\mathrm{M}} \mathrm{G}$ ratios in the various urinary metabolites of $\mathrm{E}$ and $F$ and of their specific activities as related to ${ }^{14} \mathrm{G}$ and ${ }^{3} \mathrm{H}$ supported the thesis that cortisol alone is secreted by the adrenal cortex of man [19]. However, in that investigation, as in the present work, the lack of sensitivity of the theoretical model employed did not permit to exclude any cortisone secretion. 
Table VI

\begin{tabular}{|c|c|c|c|c|c|c|c|c|}
\hline \multirow{2}{*}{ Treatment } & \multicolumn{2}{|c|}{ Controls } & \multicolumn{2}{|c|}{ Women "on pill" } & \multicolumn{2}{|c|}{ Mothers } & \multicolumn{2}{|c|}{ Cord } \\
\hline & $\mathbf{E i}$ & F2 & $\mathbf{E i}$ & F2 & $\mathbf{E}^{\mathbf{I}}$ & $\mathrm{F}^{2}$ & Ei & $F^{2}$ \\
\hline \multirow[t]{2}{*}{${ }^{8} \mathrm{H}$-Cortisone infused } & 27.2 & 66.1 & 38.5 & 185.0 & 23.9 & 92.7 & 25.2 & 6.5 \\
\hline & \pm 7.8 & \pm 22.2 & \pm 14.6 & \pm 67.2 & \pm 6.8 & \pm 32.3 & \pm 9.8 & \pm 2.2 \\
\hline \multirow{2}{*}{${ }^{14} \mathrm{C}$-Cortisol infused } & 20.4 & 107.3 & 30.2 & 262.1 & 18.4 & 122.2 & 28.8 & 6.7 \\
\hline & \pm 5.8 & \pm 28.7 & \pm 11.4 & \pm 108.2 & \pm 6.1 & \pm 47.9 & \pm 9.4 & \pm 2.8 \\
\hline Significance & $P<0.005 I$ & $P<0.01$ & $P=0.01$ & $P=0.025$ & $P=0.01$ & $P<0.005$ & $P=0.025$ & N.S. ${ }^{3}$ \\
\hline
\end{tabular}

${ }_{1}^{1}[($ Concentration of radioactive cortisone $(\mathrm{cpm} / 100 \mathrm{ml})) /($ rate of radioactive steroid infusion $(\mathrm{cpm} / \mathrm{m}))] \mathrm{X} 100$.

2 [(Concentration of radioactive cortisol $(\mathrm{cpm} / 100 \mathrm{ml})) /($ rate of radioactive steroid infusion $(\mathrm{cpm} / \mathrm{m}))] \mathrm{X} 100$.

${ }^{3}$ N.S.: Not significant.

Percentage of Contribution of Maternal Secretion of F to Fetal Pool of $F$ and $E$

If one assumes that the values of radioactive and nonisotopic $\mathrm{F}$ and $\mathrm{E}$ determined in this study were obtained when equilibrium was reached on both sides of the placenta, then it can be concluded that the fetus near term is capable of secreting about three-fourths of its cortisol. In contrast, most, if not all of its cortisone originated from the mother. The data, however, do not permit determination of whether the cortisone crossed the placenta as such or was converted from maternal cortisol during transplacental passage, or whether there is a combination of both sources.

For the purpose of comparing plasma levels of steroids in the various subjects, the concentrations of radioactive cortisol and cortisone (in counts per minute per $100 \mathrm{ml}$ plasma) were expressed as percentage of the corresponding infusion rate. The means and standard deviations are presented in Table VI. In each group of women cortisol infusion resulted in significantly greater cortisol concentrations and significantly lower cortisone concentrations when compared to levels obtained following cortisone infusion. However, cortisol and cortisone infusions resulted in similar F and E levels in cord plasma. The therapeutic consequence of this finding is that cortisol administration during pregnancy will result in higher maternal $\mathrm{F}$ levels but similar fetal $\mathrm{F}$ values when compared with the same dose of cortisone.

In a previous study on the transplacental passage of prednisone and prednisolone, it was also found that the 11/3-hydroxylated compound gave maternal concentrations of prednisolone which were higher than those obtained following prednisone administration [4]. Whether prednisolone or prednisone was infused into the mother, the maternal/cord ratios of prednisolone concentrations were similar (9.6 and 9.7, respectively).

\section{References and Notes}

1. AARSKOG, D.: Cortisol in the newborn infant. Norwegian Monographs on Medical Science, p. 13. (Scandinavian University Books, 1964).

2. BAYARD, F., ANCES, I. G., TAPPER, A. F., WELDON, V. V., KOWARSKI, A., AND MIGEON, C. J.: Transplacental passage and fetal secretion of aldosterone. J. Clin. Invest., 49: 1389 (1970).

3. BEITINS, I. Z., BAYARD, F., ANCES, I. G., KOWARSKI, A., AND MIGEON, C. J.: The transplacental passage of prednisone and prednisolone in pregnancy near term. J. Pediat., 81: 936 (1972).

4. BEITINS, I. Z., KOWARSKI, A., SHERMATA, D. W., DE LEMOS, R. A., AND MIGEON, C. J.: Fetal and maternal secretion rate of cortisol in sheep: Diffusion resistance of the placenta. Pediat. Res., •*: 129 (1970).

5. BEITINS, I. Z., SHAW, M. H., KOWARSKI, A., AND MIGEON, C. J.: Comparison of competitive protein binding radioassay of cortisol to double isotope dilution and Porter-Silber methods. Steroids, 15: 765 (1970).

6. BERLINER, D. L., JONES, J. E., AND SALHANICK, H. A.: The isolation of adrenal-like steroids from the human placenta. J. Biol. Chem., 223: 1043 (1956).

1. BRADLEY, E. M., AND WATERHOUSE, C: Effect of estrogen administration on extravascular cortisol. J. Clin. Endocrinol., 26: 705 (1966).

8. BRO-RASMUSSEN, F., BUUS, O., AND TROLLE, D.: Ratio cortisone/cortisol in mother and infant at birth. Acta Endocrinol., 40: 579 (1962).

9. DE LACERDA, L., KOWARSKI, A., AND MIGEON, C. J.: Integrated concentration of plasma cortisol in normal subjects. J. Clin. Endocrinol., 36: (in press).

10. DE LACERDA, L., KOWARSKI, A., AND MIGEON, C. J.: Diurnal variation of the metabolic clearance rate of cortisol: Effect on measurement of cortisol production rate. J. Clin. Endocrinol. (in press).

11. DIXON, W. J., AND MASSEY, F. J.: Introduction to Statistical Analysis, p. 116. (McGraw-Hill Book Company, New York, 1969).

12. EBERLEIN, W. R.: Steroids and sterols in umbilical cord blood. J. Clin. Endocrinol., 25: 1101 (1965).

13. EIK-NES, K., NELSON, D. H., AND SAMUELS, L. T.: Determination of 17,21-hydroxycorticosteroids in plasma. J. Clin. Endocrinol., 13: 1280 (1953).

14. GEMZELL, C. A.: Variations in plasma levels of 17-hydroxy- 
corticosteroids in mother and infant following parturition. Acta Endocrinol., 17: 100 (1954).

15. GREENBERG, A. H., CZERNICHOW, P., REBA, R. C, TYSON, J., AND BLIZZARD, R. M.: Observations on the maturation of thyroid function in early fetal life. J. Clin. Invest., 49: 1790 (1970).

16. HELLMAN, L., NAKADA, F., CURTI, J., WEITZMAN, E. D., KREAM, J., ROFFWARG, H., ELLMAN, S., FUKUSHIMA, D. K., AND GALLAGHER, T. F.: Cortisol is secreted episodically by normal man. J. Clin. Endocrinol., 30: 411 (1970).

17. HILlmAN, D. A., AND GIROUD, C. J. P.: Plasma cortisone and cortisol levels at birth and during the neonatal period. J. Clin. Endocrinol., 25: 243 (1965).

18. KONO, T., YOSHIMI, T., AND MIYAKE, T.: Metabolic clearance of aldosterone, cortisol and corticosterone in various clinical conditions. In: G. Pincus: Steroid Dynamics, p. 429. (Academic Press, New York, 1966).

19. KOWARSKI, A., LAWRENCE, B., HUNG, W., AND MIGEON, C. J.: Interconversion of cortisol and cortisone in man and its effect on the measurement of cortisol secretion rate. J. Clin. Endocrinol., 29: 377 (1969).

20. LAYNE, D. S., MEYER, C. J., VAISHWANAR, P. S., AND PINCUS, G.: The secretion and metabolism of cortisol and aldosterone in normal and steroid-treated women. J. Clin. Endocrinol., 22: 107 (1962).

21. MIGEON, C. J.: Cortisol production and metabolism in the neonate. J. Pediat., 55: 280 (1959).

22. MIGEON, C. J., BERTRAND, F., AND GEMZELL, C. A.: The transplacental passage of various steroid hormones in mid-pregnancy. Rec. Progr. Hormone Res., 17: 207 (1961).

23. MIGEON, C. J., BERTRAND, J., AND WALL, P. E.: Physiologic disposition of $4-\mathrm{C}^{14}$-cortisol during late pregnancy. J. Clin. Invest., 36: 1350 (1957).

24. MIGEON, C. J., PRYSTOVSKY, H., GRUMBACH, M. M., AND BYRON, M. C: Placental passage of 17-hydroxycorticosteroids: comparison of the levels in maternal and fetal plasma and effect of ACTH and hydrocortisone administration. J. Clin. Invest., 35: 488 (1956).

25. MURPHY, B. E. P.: Some studies of the protein-binding of steroids and their application to the routine micro and ultramicro measurement of various steroids in body fluids by competitive protein-binding radioassay. J. Clin. Endocrinol., 27: 973 (1967).

26. OSINSKI, P. A.: Steroid 11/3-ol-dehydrogenase in human placenta. Nature, 187: 777 (1960).

27. PETERSON, R. E.: The miscible pool and turnover rate of adrenocortical steroids in man. Recent Progr. Hormone Res., 15: 231 (1959).

28. PORTER, C. C, AND SILBER, C. H.: A quantitative color reaction of cortisone and related 17,21-dihydroxy-20-ketosteroids. J. Biol. Chem., 185: 201 (1950).

29. SANDBERG, A. A., AND SLAUNWhite, W. R.: Transcortin: A corticosteroid-binding protein of plasma. II. Levels in various conditions and the effects of estrogens. J. Clin. Invest., 38: 1290 (1959).

30. SCHWEITZER, M., BRANCHAUD, C, AND GIROUD, C. J. P.: Maternal and umbilical cord plasma concentrations of steroids of the pregn-4-ene C-21-yl sulfate series at term. Steroids, 14: 519 (1969).

31. SEELY, J. R.: Adrenal function in newborns: Methodology in perinatal circulating steroid patterns. Amer. J. Dis. Child., 102: 474 (1961).

32. STREETER, G. L.: Weight, sitting height, head size, foot length and menstrual age of human embryo. Contrib. Embryol. Carnegie Inst. Wash., 11: 143 (1920).

33. SYBULSKI, S., AND VENNING, E. H.: The possibility of corticosteroid production by human and rat placental tissue under in vitro conditions. Can. J. Biochem. Physiol., 39: 203 (1961).

34. TAIT, J. F., LITTLE, B., TAIT, S. A. S., AND FLOOD, C: The metabolic clearance rate of aldosterone in pregnant and non-pregnant subjects estimated by both simple injection and constant infusion methods. J. Clin. Invest., 41: 2093 (1962).

35. TROEN, P.: Perfusion studies in the human placenta. III. Production of free and conjugated Porter-Silber chromogens. J. Clin. Endocrinol., 21: 1511 (1961).

36. ULSTROM, R. A., COLLE, E., REYNOLDS, J. W., AND BURLEY, J.: Adrenocortical steroid metabolism in newborn infants. IV. Plasma concentration of cortisol in early neonatal period. J. Clin. Endocrinol., 21: 414 (1961).

37. VILLEE, D. B.: Development of endocrine function in the human placenta and fetus. New Engl. J. Med., 281: 473 (1969).

38. ZANDER, J., VON MUNSTERMANN, A., AND RUNNEBAUM, B.: Steroide im plasma von menschlichem plazentablut (Nabelschnurplasma). Acta Endocrinol., 41: 507 (1962).

39. Harvard Apparatus, Millis, Mass.

40. Obtained from New England Nuclear, Boston, Mass.

41. Nuclear-Chicago Corporation, Des Plaines, 111.

42. The authors wish to thank Mrs. Geraldine Davis and Jaqueline Kolb for their excellent technical assistance and Mrs. Doris Barrington for her expert secretarial help. We also wish to express our gratitude to Dr. A. H. Greenberg who kindly supplied some of the fetal plasma samples.

43. The present address of Dr. I. Z. Beitins is: Department of Pediatrics, The Children's Hospital, 219 Bryant Street, Buffalo, New York 14222; of Dr. F. Bayard is: Centre Hospitalier Regional, de Toulouse Hospital, Purpan, Bloc d'Urgence Medicale, Toulouse 31, France.

44. This work was supported by Research Grant no. AM-00180, Traineeship Grant no. Tl-AM-5219, and Research Career Award no. 5K06-AM-21,855 (CJM), National Institutes of Health, United States Public Health Service.

45. Requests for reprints should be addressed to: CLAUDE J. MIGEON, M.D., The Johns Hopkins Hospital, Baltimore, Md. 21205 (USA)

46. Accepted for publication December 21, 1972. 